\title{
Concept Analysis: Family Resilience
}

\author{
Seieun Oh1', Sun Ju Chang² \\ ${ }^{1}$ Department of Nursing, Dankook University, Cheonan, South Korea \\ ${ }^{2}$ Department of Nursing Science, Chungbuk National University, Cheongju, South Korea \\ Email: seieun5@dankook.ac.kr, sjchang@chungbuk.ac.kr
}

Received 30 October 2014; revised 30 November 2014; accepted 16 December 2014

Copyright (C) 2014 by authors and Scientific Research Publishing Inc.

This work is licensed under the Creative Commons Attribution International License (CC BY). http://creativecommons.org/licenses/by/4.0/

\section{(c) (i) Open Access}

\section{Abstract}

Background: Although the concept of family resilience has had increased popularity in recent studies, conceptual and methodological issues need to be addressed. Aim: The purpose of this paper is to analyze the current status of the concept of family resilience in research and to suggest future needed directions for research. Methods: The structure of the analysis derives from Rodgers' evolutionary concept analysis. Data for the analysis were retrieved using six electronic databases through phrasal search with "family resilience" as search terms. 38 were included in the current review. Results: Six dimensions of family resilience were identified: 1) collective confidence; 2) interconnectedness; 3) positive life view; 4) resourcefulness; 5) open communication patterns; and 6) collaborative problem-solving. Three possible antecedents of family resilience were identified: 1) perceived sense of disequilibrium; 2) spirituality/shared belief systems or religious beliefs; and 3) families' strong will to overcome adversities. Consequences of being resilient include: 1) acceptance of the situation; 2) change in life perspectives; 3 ) enhanced relationship qualities; 4) reinforcement of resilient properties; and 5) improved health-related outcomes. Conclusion: Although the concept of resilience has been adopted as a useful strength-based perspective to understand family adaptation in the presence of adversity, it still needs further conceptual and methodological refinements. Multiple dimensions, cultural differences and variations of the concept within longitudinal designs should be examined with data gathered from multiple family members in order to improve family resilience research and its application to nursing practice. Implications for future research and intervention are suggested.

\section{Keywords}

Family Resilience, Concept Analysis, Family Research

\section{Introduction}

Since the 1970s, the focus of health-related research has been redirected from disease, deficit, or vulnerability to 
individual strengths, assuming that clients possess resources which will allow them to resolve their difficulties [1] [2]. The concept of resilience has received growing attention within this strength-based construct tradition.

The concept of resilience has its historical roots in two disciplines, physiology and psychology [3]. It was introduced and flourished primarily in developmental psychopathology research that showed children competently functioned in high-risk families [4]. In the 1990s, the concept of resilience gained acceptance among family science researchers who studied family stress and coping. This acceptance initiated a movement that viewed resilience as a family-level construct [1] [4].

Perspectives on the concept of resilience have been evolving since it was introduced as a family-level construct. In traditional views, family resilience is the sum of individual family member's resilience [5]. A more contemporary perspective on family resilience emphasizes the relational properties of families as a unit or the relational processes that facilitate family survival, and even growth, under adverse conditions [6].

One of the major changes on the concept of family resilience is the difference in views on family resilience as a trait versus a process. Researchers studying family resilience can be organized into two camps: those who investigate the concept as a property of families and those who view resilience as a process of adaptation. McCubbin and McCubbin [7], seminal authors of a theory of family resiliency, defined it as "characteristics, dimensions, and properties of families which help families to be resistant to disruption in the face of change and adaptive in the face of crisis situations" (p. 247). Patterson [8] defined family resilience as a family's ability to mobilize strength actively when their lives are threatened by stressful events or crises. These definitions suggest that family resilience triggers specific processes that enable the family to regain or surpass the level of family functioning prior to stressor or crisis.

More recent studies on family resilience tend to emphasize the concept's interactive and contextual nature [9]. Resilient families respond positively to stress in unique ways, depending on the context, the length of the adversity, the family's developmental level or life stage, and the interactive combination of risk and protective factors [5]. A family may be resilient with certain stressors but may not be resilient with other levels or types of stressors.

Despite the recent popularity of the concept of family resilience, critical issues for family resilience research have been raised by family scientists. These issues range from conceptualization to methodological concerns [2] [9]. An examination of the concept of family resilience is needed to help add clarity and to provide information from which to design effective interventions for families facing adversity. The purpose of this paper is to: 1) analyze the concept of family resilience, distinguishing the antecedents, consequences, and definitional dimensions of the concept; 2) synthesize a conceptual definition of family resilience based on an analysis of the literature; 3) identify conceptual and methodological limitations in existing studies; and 4) recommend directions for future research.

\section{Methods}

\subsection{Sampling and Setting}

Primary research on family resilience for the current paper was retrieved using multiple databases, including PubMed, Cumulative Index to Nursing and Allied Health Literature (CINAHL), PsycINFO, Family Studies Database, Sociological Abstracts, and Social Sciences Citation Index. The selection criteria for retrieved studies were that they be 1) primary research with focus on both family and resilience, not individual resilience, 2) English-written only, and 3) published from January, 1995 to July, 2012. Since literature search using family and resilience as separate search terms retrieved too many studies focusing on individual resilience, phrasal search with "family resilience" was conducted to locate research eligible for the current analysis.

An initial pool of 228 articles was identified from the searched databases. Of the 228 identified publications, 111 articles were excluded including: book review (43); unpublished thesis or dissertations (22); review articles (33); commentary, editorial, and proceedings (13). Three studies the full text of which was not available were excluded. Next, 28 clinical reports (not primary research) were also excluded. Among the remaining 86 studies with full text access, 48 studies were further excluded because they did not focus on family resilience (e.g., the concept was used only to discuss results, 36) or dealt with individual or community resilience (12). Finally, 38 articles were retrieved for the current review: 17 quantitative research, 17 qualitative research, and four mixed method study (Figure 1). 


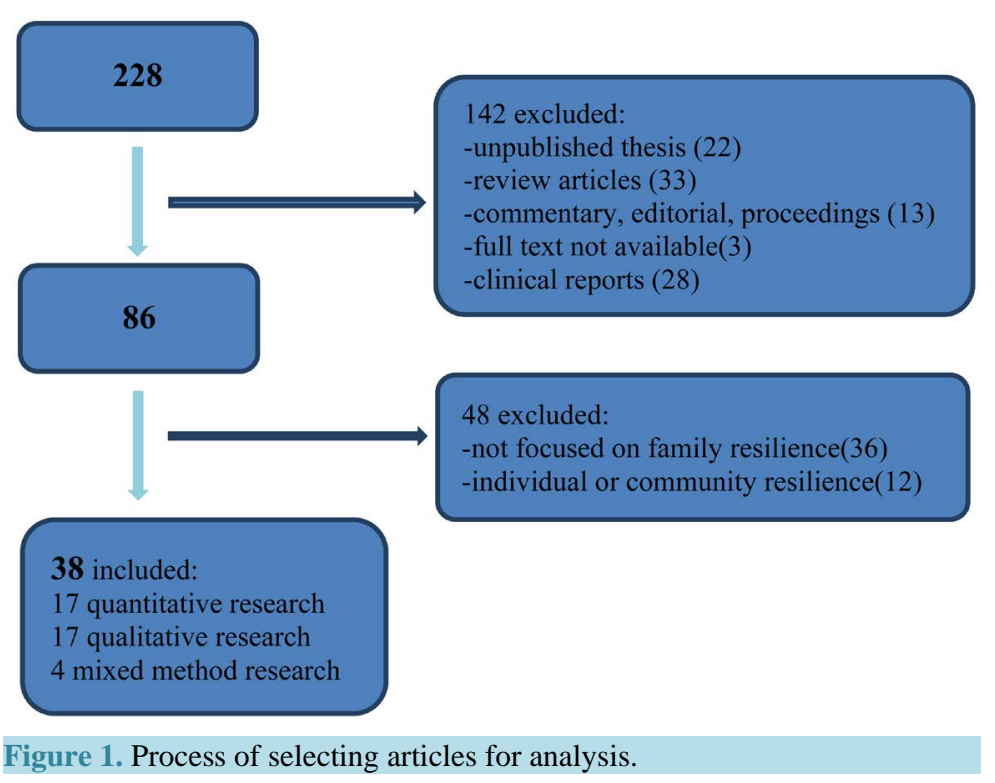

\subsection{Data Collection and Analysis}

Each selected article was analyzed based on dimensions suggested by Rodgers [10]: concept attributes, antecedents, consequences, socio-cultural context, and surrogate terms/related concepts. Information related to those five dimensions was documented during the phase of reading and re-reading selected studies. Data for each dimension were segregated and thematically analyzed. Themes that were not frequently shown but provided new information on the concept were also recorded along with the common themes identified in each dimension. Each analytic dimension was next examined separately to identify major themes presented in the literature. Out of the five analytic dimensions, three major dimensions of the analysis-attributes, antecedents, and consequences-are presented in this paper (Figure 2). Examples of the analysis (two for quantitative, two for qualitative, and two for mixed-method research) are presented in Table 1.

\section{Results}

\subsection{Attributes of Family Resilience}

According to the Oxford English Dictionary [11], resilience is defined as: the act of rebounding or springing back; to rebound, recoil from something; and elasticity: the power of resuming the original shape or position after compression or bending. Applying the definition of resilience to a family system, the concept of family resilience can refer to the families' recovery or power of recovery from life events or stressors that cause significant disruption or deformation on a family system.

An analysis of the studies on family resilience revealed six attributes of family resilience: 1) collective confidence; 2) interconnectedness; 3) positive life view; 4) resourcefulness, including perceived availability of support and capability to identify and utilize support; 5) open communication patterns; and 6) collaborative problem-solving. These six attributes are interrelated and embedded in families' patterns of functioning. Each of these six attributes is next examined.

1) Collective confidence

Resilient families hold strong beliefs that they are able to manage hardships they are facing and perceive varying degrees of control over their responses to adversities. These beliefs are shared among family members rather than those held by a particular individual family member. The sense of control in this context emphasizes the family's belief in their ability to control their response instead of controlling the situation. For example, resilient families tend to distinguish what they can change (making a choice about positive options) from those they cannot (the event itself) and focus instead on what they can do. Resilient families would therefore choose a productive or healthier response both psychologically and practically-e.g., choose not to worry and get things done, rather than being overwhelmed by adversities - when they face a critical moment of choice. These beliefs in ability were sometimes labeled as "collective efficacy", or "family mastery", or "getting on together". 


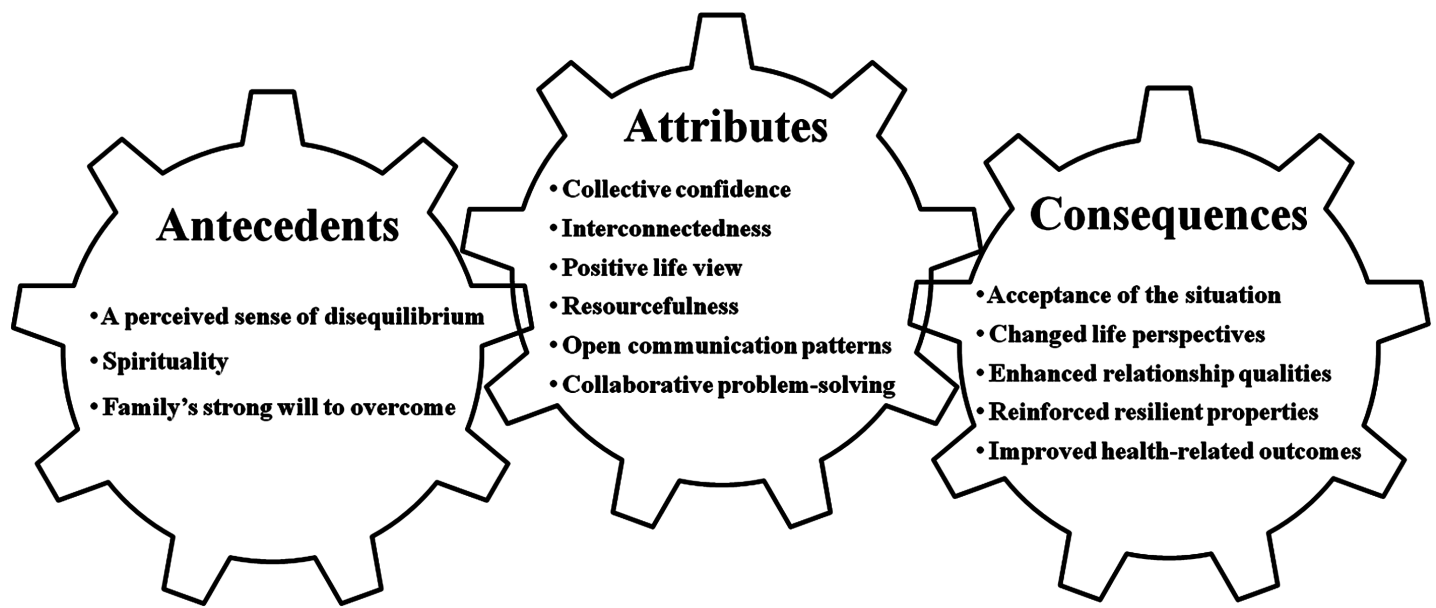

Figure 2. Three domains of concept of family resilience.

2) Interconnectedness

A resilient family shares a collective sense of connectedness, family ties, or solidarity, and a belief that they can depend on each other. It is this fundamental interconnectedness that enables the family to work as a team. Members of a resilient family share an orientation that they belong to the family-as-unit, work together, adjust individual roles and responsibilities, and are able to make a collective effort to achieve family goals. In studies of family resilience, family solidarity, cohesiveness, or cohesion are frequently used terms that refer to such properties.

3) Positive life view

Resilient families are characterized by positive and optimistic perspectives on life [1] [12]. A family's positive perspective on life affects its appraisal about adversity [13]. This perspective is closely related to the family's process of making meaning [4] and one of the family belief systems proposed by Walsh [12]. The positive life view is two-fold: specifically, the family who is resilient perceives a stressful event as challenging and manageable and concurrently, the family has a positive framework from which it views the world in general.

4) Resourcefulness

Resourcefulness involves families' perception and capability to identify and utilize social support and resources as needed. Resilient families do not need to possess all necessary resources or access to resources. Even in the absence of objective resources and support, resilient families creatively utilize whatever resources exist. The family knows there are resources available to them, and they are able to mobilize the resources and support as needed, from outside as well as within the family. In relation to social support, it is important to be in a supportive network, and the family's perception of the relationship quality within this network also matters. Even when resilient families lose their supportive network during a difficult situation, they are able to build or find a new network from which they can draw support. Support within the family was labeled as "commitment".

5) Open communication patterns

Resilient families' communication patterns were described as "open”. In these studies, the open communication pattern has two meanings: free atmosphere of expressing or sharing individual members' emotions, and the members' attitude of being forthright and productive in discussing problems.

Besides the "open” nature of resilient families' communication style, another pattern worked specifically for resilient couples. Couples who had experienced one spouse's hearing losses specified a communication pattern that balanced negative expressions with positive comments at the same time. This tended to smooth tensions when discussing sensitive issues.

6) Collaborative problem-solving

Problem solving processes in resilient families involve a set of behaviors which require collaboration between family members. These behaviors involve reallocating roles and responsibilities, rescheduling or rearranging living arrangements, and relinquishing personal desires. Through such combined efforts, new patterns of functioning or new rituals are developed and integrated into their lives for the purpose of meeting the families' new needs as well as maintaining other family routines and rituals. 
Table 1. Examples of analaysis (author-alphabetical order).

\begin{tabular}{|c|c|c|c|c|c|c|c|c|}
\hline \multirow{2}{*}{ Articles } & \multicolumn{8}{|c|}{ Analytic components } \\
\hline & $\begin{array}{l}\text { Study } \\
\text { design }\end{array}$ & Participants & $\begin{array}{l}\text { Social-cultural } \\
\text { context }\end{array}$ & $\begin{array}{l}\text { Theoretical } \\
\text { framework }\end{array}$ & Attributes & $\begin{array}{l}\text { Antecedents } \\
\text { (stressors) }\end{array}$ & $\begin{array}{l}\text { Antecedents } \\
\text { (facilitators) }\end{array}$ & Consequences \\
\hline $\begin{array}{l}\text { Ahlert } \\
\text { et al. } \\
\text { (2012) }\end{array}$ & $\begin{array}{l}\text { Mixed } \\
\text { method }\end{array}$ & $\begin{array}{l}54 \text { families } \\
\text { across four } \\
\text { racial } \\
\text { groups }\end{array}$ & $\begin{array}{l}\text { Four main racial } \\
\text { groups in South } \\
\text { Africa including } \\
\text { Black, White, } \\
\text { Colored, and } \\
\text { Indian }\end{array}$ & $\begin{array}{l}\text { Resiliency } \\
\text { model of } \\
\text { stress, } \\
\text { adjustment, } \\
\text { and } \\
\text { adaptation }\end{array}$ & $\begin{array}{l}\cdot \text { Interconnectedness } \\
\cdot \text { Resourcefulness } \\
\cdot \text { Collaborative } \\
\text { problem-solving } \\
\cdot \text { Open } \\
\text { communication } \\
\text { patterns }\end{array}$ & $\begin{array}{l}\text { s Families with } \\
\text { deaf or hard of } \\
\text { hearing children }\end{array}$ & Spirituality & $\begin{array}{l}\text { - Adaptation } \\
\text { and coping } \\
\text { with stresses }\end{array}$ \\
\hline $\begin{array}{l}\text { Greeff } \\
\text { et al. } \\
(2008)\end{array}$ & Qualitative & $\begin{array}{l}26 \text { adoles- } \\
\text { cents } \\
\cdot 51 \text { parents }\end{array}$ & $\begin{array}{l}\text { Xhosa-speaking } \\
\text { - Deeply } \\
\text { imbedded } \\
\text { spirituality in } \\
\text { Africans }\end{array}$ & $\begin{array}{l}\text { Not } \\
\text { specified }\end{array}$ & - Resourcefulness & $\begin{array}{l}\text { Experiencing } \\
\text { either the death } \\
\text { of a child or a } \\
\text { serious financial } \\
\text { setback }\end{array}$ & Spirituality & $\begin{array}{l}\text { Adaptation } \\
\text { and bounce } \\
\text { back from a } \\
\text { crisis period }\end{array}$ \\
\hline $\begin{array}{l}\text { Greeff } \\
\text { et al. } \\
\text { (2011) }\end{array}$ & $\begin{array}{l}\text { Mixed } \\
\text { method }\end{array}$ & $\begin{array}{l}\cdot 89 \text { bereaved } \\
\text { parents } \\
\cdot 67 \text { bereaved } \\
\text { siblings }\end{array}$ & $\begin{array}{l}\cdot \text { Flemish- } \\
\text { speaking } \\
\cdot \text { Belgium }\end{array}$ & $\begin{array}{l}\text { Resiliency } \\
\text { model }\end{array}$ & $\begin{array}{l}\text { - Collective } \\
\text { confidence } \\
\text { · Interconnectedness } \\
\text { · Positive life view } \\
\text { - Resourcefulness }\end{array}$ & $\begin{array}{l}\text { Experiencing } \\
\text { the death of } \\
\text { children before } \\
3 \text { to } 6 \text { years }\end{array}$ & Spirituality & $\begin{array}{l}\text { Family } \\
\text { adaptation } \\
\text { after the loss } \\
\text { (family sense } \\
\text { of coherence) }\end{array}$ \\
\hline $\begin{array}{l}\text { Levine } \\
\text { (2009) }\end{array}$ & Qualitative & $\begin{array}{l}15 \text { single } \\
\text { mothers }\end{array}$ & Not specified & $\begin{array}{l}\text { Family stress } \\
\text { and coping } \\
\text { theory } \\
\text { Family } \\
\text { adjustment } \\
\text { and } \\
\text { adaptation } \\
\text { response. } \\
\text { Family } \\
\text { resilience } \\
\text { framework }\end{array}$ & $\begin{array}{l}\text { Positive life view } \\
\cdot \text { Resourcefulness }\end{array}$ & $\begin{array}{l}\text { Single mother } \\
\text { of children } \\
\text { with disability }\end{array}$ & $\begin{array}{l}\text { Not } \\
\text { specified }\end{array}$ & $\begin{array}{l}\text { - Resilience } \\
\text { building }\end{array}$ \\
\hline $\begin{array}{l}\text { McDermott } \\
\text { et al. } \\
(2010)\end{array}$ & Descriptive & $\begin{array}{l}\cdot 568 \text { children } \\
\cdot 441 \text { parents }\end{array}$ & $\begin{array}{l}\text { A history } \\
\text { of a very } \\
\text { severe cyclone }\end{array}$ & $\begin{array}{l}\text { Not } \\
\text { specified }\end{array}$ & $\begin{array}{l}\cdot \text { Collective } \\
\text { confidence } \\
\cdot \text { Open } \\
\text { communication } \\
\text { patterns }\end{array}$ & $\begin{array}{l}\text { - Experiencing } \\
\text { a disaster } \\
\text { (cyclone) }\end{array}$ & $\begin{array}{l}\cdot \text { Not } \\
\text { specified }\end{array}$ & $\begin{array}{l}\text { Low family } \\
\text { resilience was } \\
\text { associated } \\
\text { with child's } \\
\text { emotional } \\
\text { problems }\end{array}$ \\
\hline $\begin{array}{l}\text { Shin } \\
\text { et al. } \\
\text { (2010) }\end{array}$ & Descriptive & $\begin{array}{l}\cdot 178 \\
\text { adolescents } \\
\text { with parental } \\
\text { divorce }\end{array}$ & $\begin{array}{l}\text { Three different } \\
\text { types of primary } \\
\text { caregiver in } \\
\text { divorced families } \\
\text { (fathers, mothers, } \\
\text { and grandparents) }\end{array}$ & $\begin{array}{l}\text { Resiliency } \\
\text { model of } \\
\text { family stress, } \\
\text { adjustment } \\
\text { and } \\
\text { adaptation }\end{array}$ & $\begin{array}{l}\cdot \text { Positive life view } \\
\cdot \text { Resourcefulness } \\
\cdot \text { Open } \\
\text { communication } \\
\text { patterns } \\
\cdot \text { Collaborative } \\
\text { problem-solving }\end{array}$ & - Parental divorce & & $\begin{array}{l}\text { - Adolescents' } \\
\text { adjustment }\end{array}$ \\
\hline
\end{tabular}

\subsection{Antecedents of Family Resilience}

Three conditions appear to function as antecedents or sources of family resilience in the research literature: 1) a perceived sense of disequilibrium; 2) spirituality, religious beliefs or shared belief systems; and 3) the family's strong will to overcome adversities. A perceived sense of disequilibrium can also be viewed as a potential precursor of family resilience. Although not directly measured in research, there is evidence in three published studies that there were periods of time in which participating families realized that significant changes were needed in how their family functioned.

There is suggestive evidence that spirituality is a fundamental source of family resilience. Although only two studies directly explored spirituality as a source of family resilience, nine studies viewed a family's shared belief 
system or spirituality as an essential aspect of family resilience. Results from these studies documented that a family's shared beliefs or religious beliefs provided purpose or direction to the individual member's lives, which assisted in finding reason or meaning in and acceptance of adversities.

In the research by Betin and Allen [14], Arab American couples' strong will to survive in their new environments enabled them to endure throughout hard times after September 11 terror. Life-threatening circumstances in their original countries gave the couples the force of will to relocate and survive in a new environment. Such force of will was different from the other two sources of family resilience in that it was not providing positive meaning to the adversity or making them realize need of change; instead, it allowed the families to isolate themselves from their past and focus on their present lives in the US.

\subsection{Consequences of Family Resilience}

There are five known consequences of family resilience in published studies: 1) acceptance of the situation; 2) changed life perspectives; 3) enhanced relationship qualities; 4) reinforced resilient properties; and 5) improved health-related outcomes.

1) Acceptance of the situation

Acceptance was evident in most of the qualitative studies reviewed. Acceptance of the situation followed from families' spirituality and insightfulness. Acceptance may provide the family "turning point"-from experiencing negative psychological responses to stressful life events to being assertive in maintaining the family life. Along with the acceptance, an increased sensitivity to find and be grateful for small things occurring in life and an improved overall life satisfaction were reported by families. One study showed such acceptance occurred to everyone in the family, but it was not clear in the rest of the qualitative studies because only six studies recruited multiple informants.

2) Changed life perspectives

Changes in families' views on life are realized by resilient families in various levels throughout their adaptation. Such changes are reported as an overall shift of the family's priorities in life, an experience of psychological transition from self-focused to others-focused, having a more positive or balanced life view, and reframing a family's perception from negative to positive.

3) Enhanced relationship qualities

There are two types of improvements in relationship qualities that occur as a result of family resilience. In the current analysis, relationship qualities within the families were strengthened-became more bonded, committed, more compassionate and more caring as a consequence of family resilience. Concurrently, individual family members felt themselves becoming more considerate of family members, and reported being less selfish, more mindful of individual differences, less judgmental, more patient, and more willing to help others face similar difficulties.

4) Reinforced resilient properties

Throughout the adaptation process, resilient families gain a sense of connectedness as a family and become more cohesive. Resilient families gain a sense of communal mastery or collective efficacy. Also, the families' functional competence to facilitate interaction between members was strengthened, demonstrating an improved communication quality among family members, newly developed family rules and coping skills; and an acquiring of a new network of relationships through the experience of adversity. One study reported that single mothers of children with disability developed new relationships with extended family, including her parents and siblings. Such improved relationships and properties of family resilience reveal the non-recursive nature of the family resilience.

5) Improved health-related outcomes

In intervention studies designed to examine the mediating or moderating effects of family resilience, two types of health-related outcomes were reported: increased involvement in health-promoting behaviors and reduced health-deteriorating behaviors. When family resilience factors were improved, family members reported positive parenting behaviors and increased positive interaction between parents and children, increased involvement in pro-social activities in youth, increased family involvement in help-seeking in the community, and reduced consumption of alcohol, tobacco, and other drug use among high-risk youths. One study reported that low family resilience was associated with increased emotional problems in children experiencing a severe cyclone. 


\subsection{Synthesized Conceptual Definition of Family Resilience}

A conceptual definition of family resilience is synthesized from the results of the current analysis: family resilience refers to the family's capabilities to regain its psychological and functional integrity after adversity. Although it has been acknowledged among theorists and researchers that family resilience can be better understood as a process, the current analysis revealed that it still can be conceptualized as capabilities because family resilience is an outcome of interaction between a family's vulnerabilities and strengths, which happens under the specific, individualized context of families experiencing adversity. Subsequently, it is also acknowledged that the concept is not a static condition that a family holds throughout its life stages because of the contextual variations, nature of stressors, and the combination of a family's vulnerabilities and resources at times of hardship.

\section{Discussion}

Seven points need critical consideration in future research: 1) investigating different dimensions of the concept and their predictability of the outcome; 2) examining the effects of a family's cultural background; 3) identifying what a resilient family does not do; 4) investigating the concept within longitudinal designs; 5) avoiding overreliance on a single informant to represent the entire family; 6) conducting methodological studies to develop family-level measures of resilience; and 7) analyzing data obtained on family resilience using methods appropriate to the non-recursive nature of family resilience. Each aspect will be discussed in detail next.

Additional research needs to examine different dimensions of family resilience and test which dimensions are predictive of more positive outcomes in a household. This analysis showed that the concept of family resilience has multiple dimensions, but it was mostly tested by measuring the level of family hardiness. Although the concept of family hardiness shares some common dimensions with family resilience, such as collective confidence and a positive life view, other dimensions or sets of the concept's multiple dimensions also need to be examined in order to identify the most appropriate indicators of family resilience in specific conditions. Emphasis should include the conditions under which the research is conducted (participants' ethnic groups, type of stressors, etc.); these conditions require careful examination because resilient families in this analysis did not follow identical pathways to their successful outcomes of adaptation.

Future research needs to include the effects of a family's cultural background and the processes by which that background may affect its processes of appraising and making meaning of adversity. A specific culture provides an ontological orientation that forms a basis for worldviews of individuals living within that culture, which determines the individual's behaviors [15]. Thus, a family's cultural background may place different emphases on each dimension of family resilience, and the sets of these dimensions may vary by culture. In the current analysis, over half of the studies examined the concept with only Caucasian families, applying it to multiple ethnic groups in the US without considering possible cultural differences. Examining cultural differences and their influences on the dimensions of and processes triggered by family resilience will enhance the preciseness of testing the concept and help develop culturally appropriate interventions for specific ethnic groups in the community.

In addition, what a resilient family does not do may be as important as what it does do. In the literature, what a resilient family does appears to have received the most attention. However, depending on the nature of adversities and a family's cultural background, "doing nothing aggressive or assertive and waiting" may be one of the characteristics of family resilience. For example, a research on Arab-American couples dealing with cultural backlash after the 9/11 terror showed that the couples did not try to do anything assertive, instead endured the adversity and maintained their everyday lives until the situation improved; they were successful in adapting to their post-9/11 lives in the US [14]. These families are different from other resilient families who changed their subjective meanings or perspectives on their difficulties. When a family perceives a difficult situation or hardship for which it has no recourse, family resilience may be manifested in the family's steadfast endurance and its choice to do nothing assertive or aggressive within the situation [14] [16]. These resilient families may be naively perceived as passive, but their ways to adapt to the adversity actually reflects resilience more than passivity.

Family resilience also needs to be examined within longitudinal, not cross-sectional, designs. In the current analysis, 12 out of 15 quantitative studies were conducted with cross-sectional design. Conceptually, families considered resilient should display the same or higher level of functioning or outcomes of interests as they fulfill their family functions than they did in their pre-stressor experiences. In order to do so, family functioning should 
be measured at least two times compare the functioning level before and after the stressful experience. More importantly, the non-recursive nature of the concept makes it harder to distinguish its antecedents and consequences from its attributes within cross-sectional design. It is crucial to distinguish between precursors, attributes, and consequences of family resilience so that nursing interventions can be better targeted. A processoriented approach to the concept that requires longitudinal design will assist to clarify those three aspects within specific contexts.

Future research should avoid over-reliance on a single informant to represent the entire family. Family resilience is a system-level construct, which requires two or more people in interaction with each other. Data from a single family member provide limited information for characterizing family-level processes. For example, in a study that explores the impact of daughters' religious intensification on the relationship between motherdaughter pairs [17], each member of pairs reporting their relationship as positive or improved accounted for the improvements in different ways: the mothers attributed it to mutual acceptance and open discussion, whereas the daughters rationalized it by their own religious change, their family values, and the influence of religious mentors. It is possible that if only the mother or the daughter represents their family, the results can be substantially different, which may provide inaccurate information to develop family intervention to increase their family resilience. In slightly more than half of the studies reviewed (16 out of 31), data were gathered from single family members (mostly female), which eliminated the possibility of identifying such differences among family members. Therefore, it is urged to have two or more family members participate in order to understand better familylevel processes in relation to family resilience.

Subsequently, gathering data from multiple family members requires methodological studies to develop family-level measures of resilience. Having two or more family members answer questionnaires after they have reached an agreement can be an alternative. If multiple members respond to the same dimensions of family resilience, it is crucial to establish appropriate methods to deal with differences among the members' perception on each dimension of the concept.

Analyses of data obtained on family resilience needs to use methods appropriate to the non-recursive nature of family resilience. The consequences of family resilience showed that the attributes of the concept were reinforced throughout the families' experiences when facing stressors. Thus, it can be hypothesized that the more a family experiences positive adaptation to stressors, the more it becomes resilient, which had not been tested in the studies reviewed. Assessing the family's previous experience of managing life challenges and using statistical analyses combined with research designs that allow for the examination of reciprocity of previous and current experience of the family, such as prospective longitudinal designs, will help further understanding of how a family develops and maintains its resilience.

\section{Conclusion}

This analysis showed seven areas needed further improvement in future research. The concept of family resilience has multiple dimensions, parts of which have been mostly examined in empirical studies. Cultural differences and variations in the dimensions of the concept need to be investigated to determine the applicability of the concept to groups from diverse cultural backgrounds. The non-recursive nature and emphasis on relational properties of the concept need to be investigated with more precision in future research, including methodological studies to develop family-level measurement and enhance non-recursive data analyses within longitudinal designs. Such conceptual and methodological refinements of the concept will facilitate the appropriate use of the concept and its application for developing nursing interventions to enhance family resilience.

\section{Acknowledgements}

S.O sincerely appreciates the analytical assistance provided by Dr. Frances Marcus Lewis, University of Washington, School of Nursing.

\section{References}

[1] Hawley, D.R. and DeHaan, L. (1996) Toward a Definition of Family Resilience: Integrating Life-Span and Family Perspectives. Family Process, 35, 283-298. http://dx.doi.org/10.1111/j.1545-5300.1996.00283.x

[2] Richardson, G.E. (2002) The Metatheory of Resilience and Resiliency. Journal of Clinical Psychology, 58, 307-321. http://dx.doi.org/10.1002/jclp.10020 
[3] Tusaie, K. and Dyer, J. (2004) Resilience: A Historical Review of the Construct. Holistic Nursing Practice, 18, 3-8. http://dx.doi.org/10.1097/00004650-200401000-00002

[4] Patterson, J. (2002) Understanding Family Resilience. Journal of Clinical Psychology, 58, 233-246. http://dx.doi.org/10.1002/jclp.10019

[5] Simon, J.B., Murphy, J.J. and Smith, S.M. (2005) Understanding and Fostering Family Resilience. The Family Journal: Counseling and Therapy for Couples and Families, 13, 427-436. http://dx.doi.org/10.1177/1066480705278724

[6] Oswald, R.F. (2002) Resilience within the Family Networks of Lesbians and Gay Men: Intentionality and Redefinition. Journal of Marriage and Family, 64, 374-383. http://dx.doi.org/10.1111/j.1741-3737.2002.00374.x

[7] McCubbin, H.I. and McCubbin, M.A. (1988) Typologies of Resilient Families: Emerging Roles of Social Class and Ethnicity. Family Relations, 37, 247-254. http://dx.doi.org/10.2307/584557

[8] Patterson, J. (1995) Promoting Resilience in Families Experiencing Stress. Pediatric Clinics of North America, 42, 4763.

[9] De Haan, L., Hawley, D.R. and Deal, J.E. (2002) Operationalizing Family Resilience: A Methodological Strategy. The American Journal of Family Therapy, 30, 275-291. http://dx.doi.org/10.1080/01926180290033439

[10] Rodgers, B.L. (2000) Concept Analysis: An Evolutionary View. In: Rodgers, B.L. and Knafl, K.A., Eds., Concept Development in Nursing: Foundations, Techniques, and Applications, Saunders, Philadelphia, 77-102.

[11] Oxford Dictionaries (2014) Resilience. http://www.oxforddictionaries.com/definition/english/resilience

[12] Walsh, F. (2003) Family Resilience: A Framework for Clinical Practice. Family Process, 42, 1-18. http://dx.doi.org/10.1111/j.1545-5300.2003.00001.x

[13] McCubbin, H.I., Thompson, A.I. and McCubbin, M.A. (1996) Family Assessment: Resiliency, Coping and Adaptation. University of Wisconsin Publishers, Madison.

[14] Beitin, B.K. and Allen, K.R. (2005) Resilience in Arab American Couples after September 11, 2001: A Systems Perspective. Journal of Marital and Family Therapy, 31, 251-267. http://dx.doi.org/10.1111/j.1752-0606.2005.tb01567.x

[15] Yamashiro, G. and Matsuoka, J. (1997) Help-Seeking among Asian and Pacific Americans: A Multiperspective Analysis. Social Work, 42, 176-186. http://dx.doi.org/10.1093/sw/42.2.176

[16] Lietz, C.A. (2007) Uncovering Stories of Family Resilience: A Mixed Methods Study of Resilient Families, Part 2. The Journal of Contemporary Social Services, 88, 147-155. http://dx.doi.org/10.1606/1044-3894.3602

[17] Roer-Strier, D. and Sands, R.G. (2001) The Impact of Religious Intensification on Family Relations: A South African Example. Journal of Marriage \& Family, 63, 868-880. http://dx.doi.org/10.1111/j.1741-3737.2001.00868.x 


\section{List of Studies Analyzed}

[1] Ahlert, I.A. and Greeff, A.P. (2012) Resilience Factors Associated with Adaptation in Families with Deaf and Hard of Hearing Children. American Annals of the Deaf, 157, 391-404. http://dx.doi.org/10.1353/aad.2012.1629

[2] Bayat, M. (2007) Evidence of Resilience in Families of Children with Autism. Journal of Intellectual Disability Research, 51, 702-714. http://dx.doi.org/10.1111/j.1365-2788.2007.00960.x

[3] Beitin, B.K. and Allen, K.R. (2005) Resilience in Arab American Couples after September 11, 2001: A Systems Perspective. Journal of Marital and Family Therapy, 31, 251-267. http://dx.doi.org/10.1111/j.1752-0606.2005.tb01567.x

[4] Brody, A.C. and Simmons, L.A. (2007) Family Resiliency during Childhood Cancer: The Father's Perspective. Journal of Pediatric Oncology Nursing, 24, 152-165. http://dx.doi.org/10.1177/1043454206298844

[5] Chan, Y. (2006) Factors Affecting Family Resiliency: Implications for Social Service Responses to Families in Hong Kong. Indian Journal of Social Work, 67, 201-214.

[6] Cohen, O., Slonim, I., Finzi, R. and Leichtentritt, R.D. (2002) Family Resilience: Israeli Mothers’ Perspectives. American Journal of Family Therapy, 30, 173-187. http://dx.doi.org/10.1080/019261802753573876

[7] de la Rosa, I.A., Perry, J., Dalton, L.E. and Johnson, V. (2005) Strengthening Families with First-Born Children: Exploratory Story of the Outcomes of a Home Visiting Intervention. Research on Social Work Practice, 15, 323-338. http://dx.doi.org/10.1177/1049731505277004

[8] Enns, R., Reddon, J. and McDonald, L. (1999) Indications of Resilience among Family Members of People Admitted to a Psychiatric Facility. Psychiatric Rehabilitation Journal, 23, 127-136. http://dx.doi.org/10.1037/h0095179

[9] Gardner, D.L., Huber, C.H., Steiner, R., Vazquez, L.A. and Savage, T.A. (2008) The Development and Validation of the Inventory of Family Protective Factors: A Brief Assessment for Family Counseling. Family Journal, 16, 107-117. http://dx.doi.org/10.1177/1066480708314259

[10] Giallo, R. and Gavidia-Payne, S. (2006) Child, Parent and Family Factors as Predictors of Adjustment for Siblings of Children with a Disability. Journal of Intellectual Disability Research, 50, 937-948. http://dx.doi.org/10.1111/j.1365-2788.2006.00928.x

[11] Greeff, A.P. and Holtzkamp, J. (2007) The Prevalence of Resilience in Migrant Families. Family \& Community Health, 30, 189-200. http://dx.doi.org/10.1097/01.FCH.0000277762.70031.44

[12] Greeff, A.P. and Joubert, A.M. (2007) Spirituality and Resilience in Families in Which a Parent Has Died. Psychological Reports, 100, 897-900. http://dx.doi.org/10.2466/pr0.100.3.897-900

[13] Greeff, A.P. and Loubser, K. (2008) Spirituality as a Resiliency Quality in Xhosa-Speaking Families in South Africa. Journal of Religious Health, 47, 288-301. http://dx.doi.org/10.1007/s10943-007-9157-7

[14] Greeff, A.P. and Van der Merwe, S. (2004) Variables Associated with Resilience in Divorced Families. Social Indicators Research, 68, 59-75. http://dx.doi.org/10.1023/B:SOCI.0000025569.95499.b5

[15] Greeff, A.P., Vansteenwegen, A. and Herbiest, T. (2011) Indicators of Family Resilience after the Death of a Child. Omega, 63, 343-358.

[16] Halmi, A. and Golik-Gruber, V. (2002) The Prevention and Reduction of the Consumption of Alcohol and Any Other Drugs among a High-Risk Group of Youths through Improving Family Resilience. Alcoholism: Journal on Alcoholism and Related Addictions, 38, 41-55.

[17] Heiman, T. (2002) Parents of Children with Disabilities: Resilience, Coping, and Future Expectations. Journal of Developmental and Physical Disabilities, 14, 159-171. http://dx.doi.org/10.1023/A:1015219514621

[18] Hutchinson, S.L., Afifi, T. and Krause, S. (2007) The Family That Plays Together Fares Better: Examining the Contribution of Shared Family Time to Family Resilience Following Divorce. Journal of Divorce \& Remarriage, 46, 21-48. http://dx.doi.org/10.1300/J087v46n03 03

[19] Johnson, K., Bryant, D.D., Collins, D.A., Noe, T.D., Strader, T.N. and Berbaum, M. (1998) Preventing and Reducing Alcohol and Other Drug Use among High-Risk Youths by Increasing Family Resilience. Social Work, 43, 297-308. http://dx.doi.org/10.1093/sw/43.4.297

[20] Kiehl, E.M., Carson, D.K. and Dykes, A.K. (2007) Adaptation and Resiliency in Swedish Families. Scandinavian Journal of Caring Sciences, 21, 329-337. http://dx.doi.org/10.1111/j.1471-6712.2007.00473.X

[21] Lee, I., Lee, E., Kim, H.S., Park, Y.S., Song, M. and Park, Y.H. (2004) Concept Development of Family Resilience: A Study of Korean Families with a Chronically Ill Child. Journal of Clinical Nursing, 13, 636-645. http://dx.doi.org/10.1111/j.1365-2702.2004.00845.x

[22] Levine, K.A. (2009) Against All Odds: Resilience in Single Mothers of Children with Disabilities. Social Work in Health Care, 48, 402-419. http://dx.doi.org/10.1080/00981380802605781

[23] Lietz, C.A. (2006) Uncovering Stories of Family Resilience: A Mixed Methods Study of Resilient Families, Part 1. The 
Journal of Contemporary Social Services, 87, 575-582. http://dx.doi.org/10.1606/1044-3894.3573

[24] Lietz, C.A. (2007) Uncovering Stories of Family Resilience: A Mixed Methods Study of Resilient Families, Part 2. The Journal of Contemporary Social Services, 88, 147-155. http://dx.doi.org/10.1606/1044-3894.3602

[25] Marsh, D.T., Lefley, H.P., Evans-Rhodes, D., Ansell, V.I., Doerzbacher, B.M., LaBarbera, L. and Paluzzi, J.E. (1996) The Family Experience of Mental Illness: Evidence for Resilience. Psychiatric Rehabilitation Journal, 20, 3-12. http://dx.doi.org/10.1037/h0095390

[26] McCubbin, M., Balling, K., Possin, P., Frierdich, S. and Bryne, B. (2002) Family Resiliency in Childhood Cancer. Family Relations, 51, 103-111. http://dx.doi.org/10.1111/j.1741-3729.2002.00103.x

[27] McDermott, B.M., Cobham, V.E., Berry, H. and Stallman, H.M. (2010) Vulnerability Factors for Disaster-Induced Child Post-Traumatic Stress Disorder: The Case for Low Family Resilience and Previous Mental Illness. Australian and New Zealand Journal of Psychiatry, 44, 384-389. http://dx.doi.org/10.3109/00048670903489916

[28] Mindel, C.H. and Hoefer, R.A. (2006) An Evaluation of a Family Strengthening Program for Substance Abuse Offenders. Journal of Social Service Research, 32, 23-38. http://dx.doi.org/10.1300/J079v32n04_02

[29] Orthner, D.K., Jones-Sanpei, H. and Williamson, S. (2004) The Resilience and Strengths of Low-Income Families. Family Relations, 53, 159-167. http://dx.doi.org/10.1111/j.0022-2445.2004.00006.x

[30] Parra-Cardona, J.R., Bulock, L.A., Imig, D.R., Villarruel, F.A. and Gold, S.J. (2006) “Trabajando Duro Todos Los Dias": Learning from the Life Experiences of Mexican-Origin Migrant Families. Family Relations, 55, 361-375. http://dx.doi.org/10.1111/j.1741-3729.2006.00409.x

[31] Preece, J. and Sandberg, J.G. (2005) Family Resilience and the Management of Fibromyalgia: Implications for Family Therapists. Contemporary Family Therapy: An International Journal, 27, 559-576. http://dx.doi.org/10.1007/s10591-005-8242-x

[32] Roer-Strier, D. and Sands, R.G. (2001) The Impact of Religious Intensification on Family Relations: A South African Example. Journal of Marriage \& Family, 63, 868-880. http://dx.doi.org/10.1111/j.1741-3737.2001.00868.X

[33] Shin, S.H., Choi, H., Kim, M.J. and Kim, Y.H. (2010) Comparing Adolescents’ Adjustment and Family Resilience in Divorced Families Depending on the Types of Primary Caregiver. Journal of Clinical Nursing, 19, 1695-1706. http://dx.doi.org/10.1111/j.1365-2702.2009.03081.x

[34] Svavarsdottir, E.K., Rayens, M.K. and McCubbin, M. (2005) Predictors of Adaptation in Icelandic and American Families of Young Children with Chronic Asthma. Family and Community Health, 28, 338-350. http://dx.doi.org/10.1097/00003727-200510000-00006

[35] Vandsburger, E. and Biggerstaff, M.A. (2004) Evaluation of the Stress Adjustment and Adaptation Model among Families Reporting Economic Pressure. Journal of Family Social Work, 8, 65-84. http://dx.doi.org/10.1300/J039v08n02_04

[36] White, N., Richter, J., Koeckeritz, J., Lee, Y.A. and Munch, K.L. (2002) A Cross-Cultural Comparison of Family Resiliency in Hemodialysis Patients. Journal of Transcultural Nursing, 13, 218-227. http://dx.doi.org/10.1177/10459602013003011

[37] White, N., Richter, J., Koeckeritz, J., Munch, K. and Walter, P. (2004) “Going Forward”: Family Resiliency in Patients on Hemodialysis. Journal of Family Nursing, 10, 357-378. http://dx.doi.org/10.1177/1074840704267163

[38] Yorgason, J.B., Piercy, F.P. and Piercy, S.K. (2007) Acquired Hearing Impairment in Older Couple Relationships: An Exploration of Couple Resilience Processes. Journal of Aging Studies, 21, 215-228. http://dx.doi.org/10.1016/j.jaging.2006.10.002 
Scientific Research Publishing (SCIRP) is one of the largest Open Access journal publishers. It is currently publishing more than 200 open access, online, peer-reviewed journals covering a wide range of academic disciplines. SCIRP serves the worldwide academic communities and contributes to the progress and application of science with its publication.

Other selected journals from SCIRP are listed as below. Submit your manuscript to us via either submit@scirp.org or Online Submission Portal.
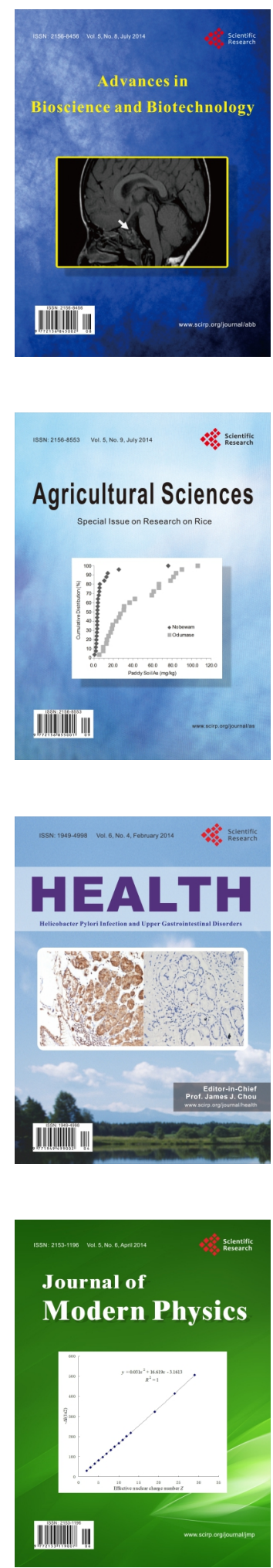
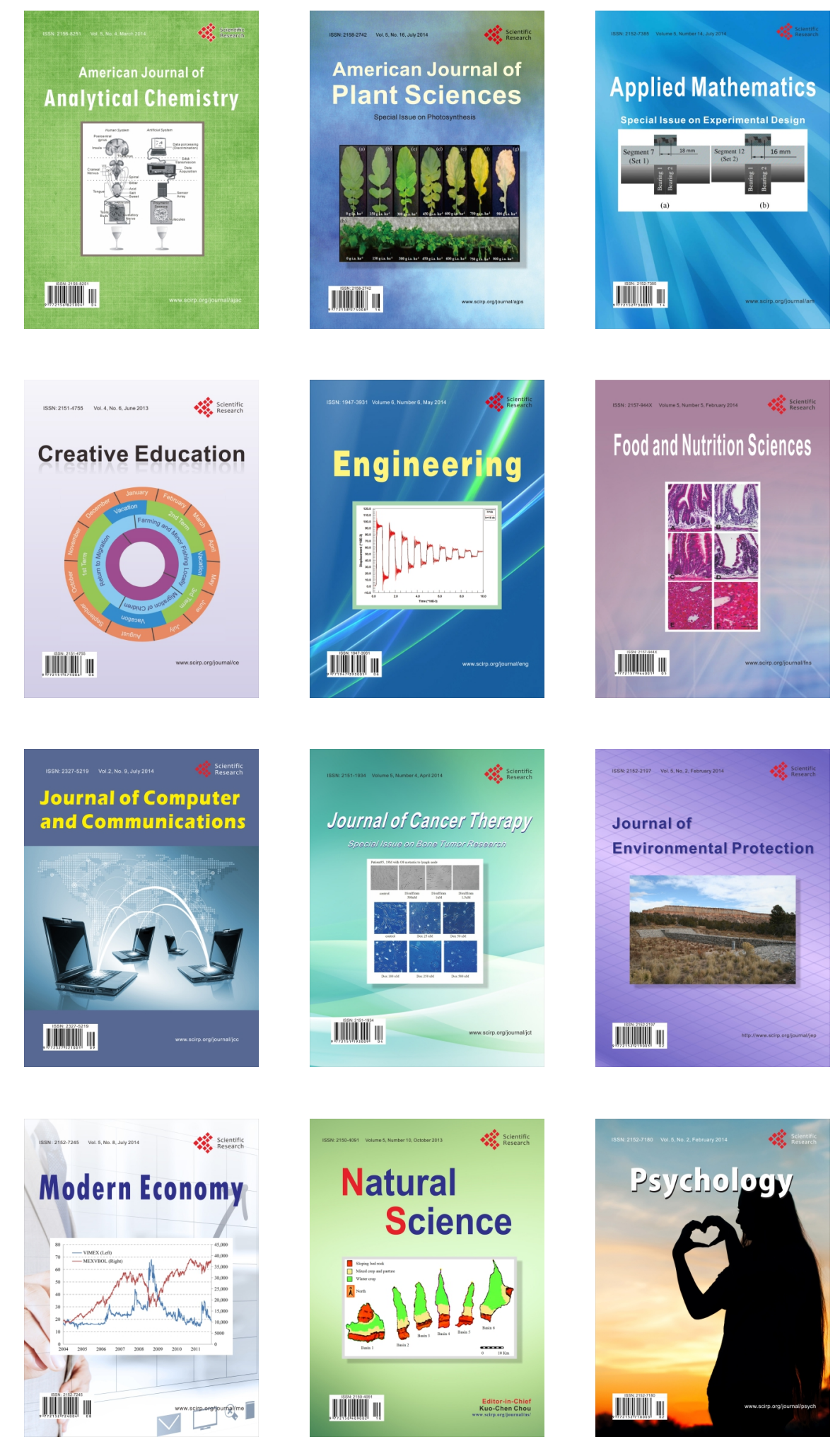